\title{
How Dutch Education Systematically Discriminates Against Dutch Immigrants and Refugees
}

\author{
Carl Hermann Dino Steinmetz \\ Expats \& Immigrants Besloten Vennootschap, Amsterdam, The Netherlands
}

\section{Email address:}

carl@expats-immigrants.com

\author{
To cite this article: \\ Carl Hermann Dino Steinmetz. How Dutch Education Systematically Discriminates Against Dutch Immigrants and Refugees. Humanities \\ and Social Sciences. Vol. 7, No. 5, 2019, pp. 141-149. doi: 10.11648/j.hss.20190705.11
}

Received: August 5, 2019; Accepted: September 2, 2019; Published: September 17, 2019

\begin{abstract}
This article investigates whether Dutch education is suitable for (grand) children of immigrants, refugees and expats with children in mainstream education. The available Dutch sociological, educational and psychological research in education and, apart from that, the education output data are the input for this investigation. The conclusion is that Dutch education should examine their consciences because on all fronts (grand) children of immigrants, refugees and expats with children in mainstream education do worse in Dutch education than (grand) children of original Dutch heritage. Children of immigrants, refugees and expats with children in mainstream education often experience disadvantage and deprivation in Dutch education. UNESCO claims that Civil Society Organizations must be held responsible to prevent (grand) children of immigrants, refugees and expats from experiencing disadvantage and deprivation in Dutch education. The tasks of these Civil Society organisations are: a) hold states accountable for their legal obligations, b) bring education concerns to the attention of a state, c) safeguard the right to education, such as providing tailor-made education as a human right, and e) hold states responsible for violations, such as disadvantage, deprivation, discrimination and exclusion.
\end{abstract}

Keywords: Education, Deprivation, Human Rights, Immigrants and Refugees, Logics, Responsibilities

\section{Introduction}

The disadvantage and deprivation of (grand) children of immigrants and refugees (including expats with children in mainstream education) by Dutch education is being investigated here [2]. In short, this research concerns pupils and students in Dutch education from the first to the fourth generation of immigrants and refugees. In this article they are considered as pupils and students, of foreign origin originally. For this investigation, they are compared with originally Dutch pupils and students. The questions addressed in this article are: a) is there disadvantage and deprivation, b) if so, how did that happen? and c) if so, what can be done about disadvantage and deprivation. At the end of the article it is indicated who can be held responsible for this disadvantage and deprivation. In order to be able to assert that with any authority, the framework "Education as a human right is used as a reference [1]."

\section{Question}

The following statement is used as a starting point here: 'discrimination and exclusion in education are pillars of social and economic inequality.' "Children in Amsterdam, from the 2008-2009 and 2009-2010 cohorts, of highly educated, white, working parents have a $67 \%$ chance of a successful school career without delay. If parents are poorly educated and unemployed, that chance is reduced to $54 \%$, and if parents also have a non-Western immigration background, then only 35 percent of children reach the finish line without any problems according to the Amsterdam Court of Audit [2]. According to the Court of Audit in Amsterdam, $50.8 \%$ of the Amsterdam children from these cohorts have successfully completed their school career [2]." The Dutch education inspectorate also launches' hopeless' as a harsh judgment about poor, crowed and unhealthy neighbourhoods in Dutch cities because 'schools in these neighbourhoods with a complex pupil and student population are hit harder by the current shortage of teachers [3]. "Where continuity and 
good quality of education are most needed, these conditions prove to be the most difficult to achieve." In short, the conclusion from these data is that deprivation and disadvantage in Amsterdam education relates to between half and two thirds of the (grand) children of immigrants and refugees [4]. However, the Education Inspectorate welcomes the fact that the inequality of opportunities does not increase further, although it is still very high [3].

Deprivation and disadvantage in education has consequences for employment perspectives for these young people of non-Dutch origin. "The State of Education has calculated that the chance of not having a job one year after graduation is 23 percent for graduates with a non-Western immigration background and 14 percent for graduates without an immigrant background [3, pp. 16]. In higher professional and scientific education, the difference between groups with and without an immigration background is smaller: 14 versus 8 percent in higher professional education and 13 versus 9 percent in higher scientific education. OECD educational-research indirectly provides international evidence for the previous results: "children of immigrants worldwide have difficulty with language, mathematics and science [5]". The OECD states that this is partly due to the feeling of not belonging at school, dissatisfaction with life, school work-related anxiety and a lack of motivation to perform [5, 7]."

The Dutch Education Council devotes special attention to refugees [6]. Its assessment is: "the quality of refugee education is insufficient because there is a lack of expertise and good teaching materials. Schools lack knowledge of Dutch as a second language (NT2), as well as knowledge of international competencies and (signalling of) traumas. The educational materials used (intake instruments, methods and tests) are often outdated [6]."

What are the causes of this deprivation and disadvantage in Dutch education for pupils and students from abroad? A number of factors are outlined in Figure 1.

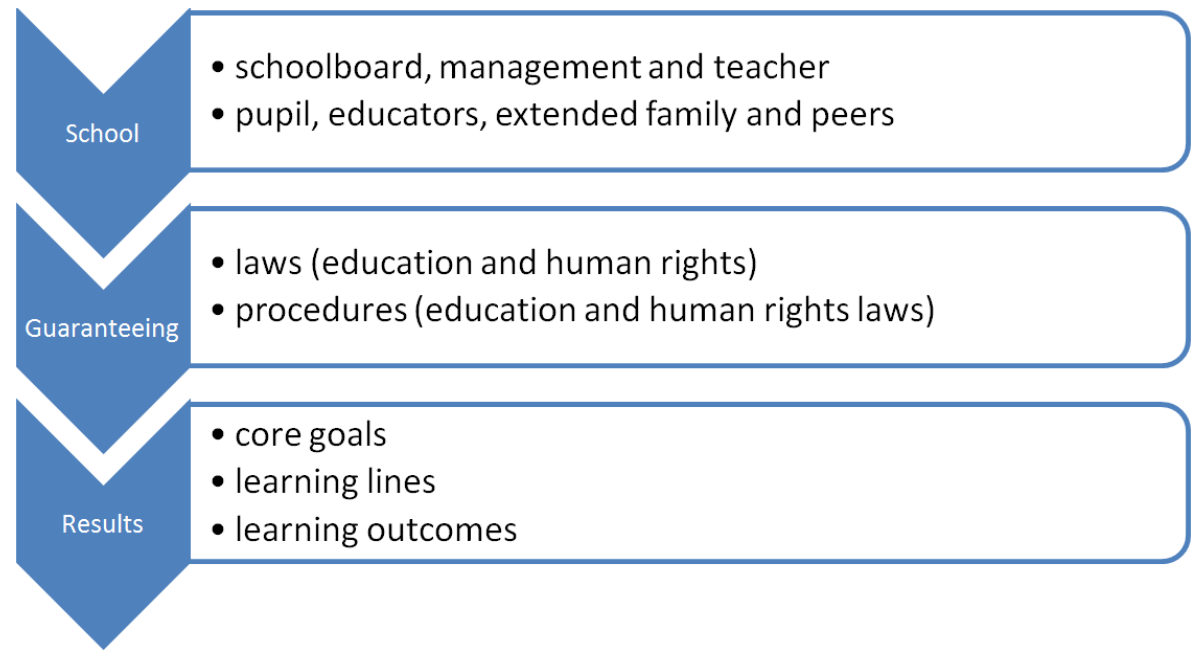

Figure 1. Causes of deprivation.

Causes of deprivation and dissatisfaction of pupils and students of foreign descent must be sought in schools (primary school (PO), secondary education (VO), secondary vocational education (MBO), higher professional education (HBO) and scientific education (WO)), in guaranteeing highquality education and same education results of pupil and student. At school, it's about quality of education and learning. Delivering quality is the responsibility of the teacher, management and schoolboard, and moreover of educators, extended families, neighbours and finally pupil/ student and her/his peers. The government of the Netherlands, parliament (second and first chamber) are responsible for ensuring education in laws and procedures. Finally, learning at school means investment in attainment of core goals, learning outcomes and learning lines. The Education Inspectorate supervises this.

\section{Systemic Deprivation in Education}

After primary school, there are in the Netherlands two school options that students can choose from, namely VMBO (basic vocational, managerial, mixed and theoretical (Mavo) learning track), and HAVO/VWO (profiles nature \& health, nature \& technology, culture \& society and economy). Education takes place on the playing field of core goals and learning outcomes that are determined by the government, with intermediary process steps such as curriculum development (content, design and testing of curriculum) and educational development (content, design and testing of the curriculum) [7]. This playing field lacks an intake and diagnosis procedure with corresponding follow-up steps, such as an approved curriculum by educators, pupils and teachers, an evaluation and adaptation. It is also not clear in advance which diagnoses can be considered as a result of the intake. The most important differentiation is that of the school directions: VMBO and HAVO-VWO. Socrates' warning ( $\dagger 399$ before the common era) fits with this differentiation of school systems: "Education is the kind of a flame, not the filling of a vessel."

How 'dropout' occurs among pupils of foreign origin in 
Dutch education depends primarily on social segregation (Our Kind of People crawls together) - and secondly on geographical segregation (caused by the price level of rental and owner-occupied homes in neighbourhoods of cities) [8, 9]. School and socio-economic segregation are interrelated: "segregation as a result of the educational level of educators in the Netherlands is relatively high. The nature of integration seems to be changing [9]. Ethnic segregation is decreasing, while segregation along the socio-economic differences (income and education) is increasing. This means that there are fewer and fewer schools in the Netherlands where specific ethnic groups dominate, but that schools are increasingly segregated by environment of the parental and familial educators."

The sociologist Crul further shows that the Dutch education system for pupils/students of foreign origin resembles a river in which salmons move upstream in order to be able to reproduce. Along the way they run the risk of being eaten by birds, bears and other animals that like to catch a fish [10]. Specifically, Crul describes the dropout in the Dutch education for the descendants of Moroccans and Turks [10]. This 'dropout' starts with 'poor' learning of Dutch and the language of their motherland and also with children who don't follow pre-school (the number of pupils in pre-school is decreasing). The 'dropout' increased further in primary education with the obstacles of under-advice, a culturally biased final test and a 'forced' transition from primary school to secondary education at the age of approximately twelve years. Crul places the responsibility for this 'dropout' in the domain of communication between educators, students and teachers about how to tackle the obstacles causing dropout. He calls this perspective the 'integration context theory'. Success (ending up at the 'right' level) and failure (ending below the 'right' level) depend on how educators, students, and teachers communicate with each other about the obstacles and 'dropout' mechanism [10]. Moreover, the obstacles described above are firmly anchored in the Dutch education legislation system.

Fortunately, Dutch education for (grand) children of Turks and Moroccans does not only look bad. Even with insufficient social and cultural capital among educators, these (grand) children can still go far in education [11]. Crul calls this multiplier effect and calls these (grand) children who achieve good results, the successful second generation [11].

\section{Psychological Deprivation and Disadvantage by Education}

A glimpse into the kitchen of primary education for (grand) children of immigrants (Moroccan, Turkish, Surinamese and Antillean) in the Netherlands is shown by the psychologist Ftitache who compares the performance and behaviour of (grand) children of non-Western immigrants with original Dutch (grand) children. The comparison of these children and their teachers takes place of from group two/three (five or six years) to group eight (eleven or twelve years) of primary school via repeated measurements. This comparison yields a number of remarkable conclusions [12].

First of all, (grand) children of originally non-Western descent have more emotional, psychological (unable to concentrate and hyperactive), cultural (forced transitions consequences as a result of two different living environments, at home and at school) and social adaptation problems than children of originally Dutch descent, resulting in increased levels of stress. Ftitache states that: "the teacher and peer reports point to increased levels of behavioural problems, oppositional rebellious behaviour, lower levels of social skills and more exclusion of (grand) children of originally non-Western descent than originally Dutch children over the entire primary school period. These adjustment problems are already present in group 3 and are still present in group 8 . These adjustment problems remain invisible to teachers and classmates [12]."

Secondly, (grand) children of non-Western descent are being bullied more, rejected for a long time and less appreciated in class than children of originally Dutch descent, what, by the way, starts at a very young age. This can be very stressful for (grand) children of non-Western descent because social harmony in the class is highly appreciated in collectivism. Psychological and social problems of (grand) children of non-Western origin are oppositional rebellious behaviour, antisocial behaviour, aggression and relational problems with peers. That children of non-Western origin are being bullied and not appreciation [12], can be described as exclusion mechanisms that increase the likelihood of a short-term psychosis [13]. "Belonging to a 'minority' implies that there is twice as much risk of a psychosis. The short-term psychosis risk of Moroccan young men is even five times higher than that of Moroccan young women [13]."

Thirdly, the invisibility at school of problems of nonWestern students among teachers and Dutch peers is probably caused by cultural differences in the expression of psychological stress, expression of emotions, cultural bias, the display of externalizing behaviour, and the feeling 'as if they don't belong'.

In the fourth place, poverty, debts, low SES (social economic status), discrimination and exclusion are possible explanations for differences in performance and behaviour between children of non-Western origin and 'Dutch' children. The above risk factors can create a new risk, namely the lack of support for children and young people by their extended family. Poverty, low SES, discrimination and exclusion have an impact on our brains: "poor people do stupid things [14]." Poverty, debt, discrimination and exclusion can lead to poorer personal- and collective decisions.

Finally, (grand) children of non-Western immigrants often receive worse Cito test results and lower school advice [10, 12]. "The relatively lower performance of children with a non-Western background on the national Cito Final Test Primary Education in group 8 can be explained by their substantial developmental delay in cognitive skills (language, working memory and attention). Interventions aimed at 
reducing ethnic educational disparities could be more effective through early, intensive stimulation and promotion of linguistic and non-linguistic cognitive skills among immigrant young people with a non-Western background. Teachers place the responsibility for poor test results and a poor school advice in the event of a lack of cognitive exercises and under-stimulation by the home environment [12]."

These psychological results correspond to the OECD's educational results on immigrants in EU countries $[12,5]$ : "poor educational results of (grand) children of foreign descent who have difficulties with language performances, mathematics and science, are caused by the feeling that they are not heard and seen at school, their dissatisfaction with life, school work related anxiety and lack of motivation to perform [7]."

\section{Possible Hypothesis for Causes of Deprivation and Disadvantage}

Almost a quarter of the Dutch population has an immigration background [15]. In the large cities of the Netherlands, Amsterdam, The Hague and Rotterdam, more than half of the population is (ex) immigrant and (ex) refugee. In Utrecht that is more than one third of the population. The majority of immigrants live in the Randstad (total population of 8.2 million in 2016) and in particular in the four major cities of the Randstad. The (grand) children of originally foreign origin in large cities in the Randstad are in the majority $(70 \%$ or more). These numbers require that those responsible for Dutch education must take action.

The previously described sociological and psychological deprivation of (grand) children of originally foreign origin in Dutch education raises the following questions: A) are the psychological and social deprivations the result of 'white' Dutch education? B) are the cognitive, psychological and social disadvantages the result of (neo) colonization, immigration and flight from a mother country and a history of extended families of immigrants and refugees to which the Netherlands has not paid attention?, and finally, C) are the cognitive, psychological and social deprivation the consequence of exclusion, deprivation and discrimination by politics, city and neighbourhood, education, labour market and health care?

Undoubtedly, many more hypotheses can be formulated based on the findings of Crul, Ftitache and the Amsterdam Court of Audit [10, 12 and 7]. In the following, particular attention is paid to the first hypothesis A. Hypothesis B and C can be seen as a further elaboration of hypothesis A.

First, it is clarified what a teacher-advice and a central final test are and what the consequences are of incorrectly applying this to (grand) children of foreign origin.

\subsection{The Teacher-Advice and Central Final Test as Predictors of Deprivation and Disadvantage}

CBS data (119,751 pupils and students) from the 2014-
2015 school year have been used to investigate whether predictions can be made using the central final test (VMBO, $\mathrm{VMBO} / \mathrm{HAVO}, \mathrm{HAVO} / \mathrm{VWO}$ and VWO advice) and the teacher-advice, each individually or together, of the educational level of a student in the third year of secondary education [16]. Together, both instruments predict $56.1 \%$ the level (= type of education) of students in the third grade of secondary education well. For $29.4 \%$ of the pupils, the central final test results are higher than the teacher advice and for $14.5 \%$ lower. These rather poor predictions are the result of the up or down stream of pupils/students. In total, one third of the pupils change levels between the end of primary school and the third year of secondary education. Downstream change of level takes place at $61 \%$ of the total of switchers [16]. How this works for (grand) children of originally foreign origin compared to Dutch children, is guesswork. It is expected that these deprivation and disadvantage mechanism will have adverse effects for (grand) children of immigrants, refugees and expats with children in mainstream education.

This discrepancy between the central final test and teacheradvice has been on the market for a while. That is why the Dutch Institute of Applied Sciences (ITS) developed a manual for enhancing the teaching advice for the Primary Education Council [17]. According to ITS, the most important determining factor in teacher-advice is the pupils calculation and language-reading performance. In addition to learning performance, according to the ITS, social-emotional characteristics are also taken into account in the teachers advice, while support at home and command of the Dutch language are less strongly taken into consideration. According to the ITS, non-cognitive characteristics, such as commitment and work attitude, play a modest role in school advice, which is also true for the social environment. Furthermore, according to the ITS, 69 percent of teachers indicate that 'in case of doubt' the behaviour of students is considered important when making a decision, while 15 percent think that the social background of pupils is an important characteristic that should be taken into account in the teacher-advice. These data are a confirmation of the results of the Ftitache study [12].

Words as 'most important' and 'decisive' are concealing. In explaining predictive factors, researchers use specific concepts such as explained variance and how statistically independent the predictive factors are. It is conceivable that social-emotional characteristics influence learning performance and vice versa, and also that all of these factors added together may hardly contribute to the teacher-advice (total explained variance), since the aforementioned statistical concepts are lacking.

According to the ITS, the education inspectorate suggests that teacher-advice tends to be higher in the period between 2003-2011 [17]. After this period, the higher teacher-advice stabilizes. According to the ITS, the student tracking system for regular test scores explains a larger part of the school advice and the position of students after four years of secondary education than the score on the Cito Final Test. In 
particular, reading comprehension, mathematics and spelling performance in groups 6 to 8 can also be used as a good foundation for the teacher-advise. The student-trackingsystem-tests in groups 6,7 and 8 together predict 57.5 percent of the performance of a student after four years of secondary education, for those of groups 7 and 8 , it is 57 percent. With the Cito Final Test that is 50 percent. In conclusion, it can be said that for more than two-fifths of the students, the Cito Final Test and the student-tracking-systemtests do not correspond to the performance of a student after 4 years of secondary education. Although calculated completely differently, this outcome exposes the same disadvantage and deprivation as that what is documented by Lek [16].

The exposed deprivation and disadvantage of pupils and students raises the question whether the teacher-advice should be adjusted on the basis of the outcome of the Cito (like) final test or vice versa. The publication "State of Education of the Education Inspectorate" states that [18]: "The teacher-advice is adjusted more often among pupils with an immigration background and highly educated parents of original Dutch pupils. In 2017, just like a year earlier, one in three students is eligible for reconsideration of the teacheradvice, because their test score is higher than expected. Just as in the previous year, the advice has been adjusted for one in three students where the test results indicate a teacheradvice of at least one level higher than the original advice. Adaptation of teacher-advice is more often found among students with a non-Western immigration background than among students without an immigration background. However, the teacher-advice of students without an immigration background is adjusted more often if their parents are highly educated. Adjustment, however, hardly reduces the differences."

\subsection{Interim Conclusion About a Possible Deprivation and Disadvantage Hypothesis}

Although hypothesis A (are sociological- and psychological deprivation the result of 'white' Dutch education?) has been investigated here, the foregoing appears to support hypothesis $\mathrm{C}$ (are the cognitive, psychological and social disadvantages found to be the result of exclusion, discrimination and discrimination by politics, city and neighbourhood, education, labour market and health care?) instead of hypothesis A. The support can be deduced from the established cohesion between socio-economic and school segregation, the limited predictive power of the combination of teacher-advice and central final test and the need to adjust the teacher-advice for (grand) children of originally foreign origin.

\section{Type of Logic as a Frame for Disadvantaged and Deprivation Causes}

The question, whether Dutch education is tailored to (grand) children of originally foreign origin is again being raised. This time, different logics will be used as a reference in combination with the underlying question: "are these (grand) children unknowingly and unintendedly disadvantaged by Dutch education in their social, practical and academic skills [19]?"

Dutch and European political immigrant and refugee logic. This logic is: "they (immigrants, refugees and expats) do not want to learn Dutch, they do not want to work, only the language of the mother country is spoken at home, they lock themselves up in their own community, they suppress their girls and women, educators cannot support and guide their children, and many educators are illiterate". The evidence that this logic could exist, can also be derived from the work of the OECD [5].

Educational and bureaucratic logic. This logic mainly concerns the government, and the parliamentary decisionmaking in the second and first chamber of Dutch parliament. The educational and bureaucratic logic uses core objectives and learning lines. In concrete terms, this logic is about what a child should master at the end of primary and secondary school. The core goals support the development of children and are used as a monitoring tool to ensure that there is an ongoing learning and development line from pre-school to the end of primary and secondary education. In a learning line, the core goals set by the government are elaborated into concrete goals that indicate what a child needs to know and can do. In the Netherlands, implementation of educational goals is entrusted to school boards at a distance from the government (national and local). Core goals and learning outcomes are maintained on behalf of the central government by the Education Inspectorate, which has sanction instruments at its disposal, should quality be at stake. The educational and bureaucratic logic use concepts such as caution, efficient division of labour, reliability and legal equality [20]. Equality of law functions with the grace of reliability. Careful compliance with rules guarantees that pupils and students are treated equally despite their differences." That means that tailor-made solutions are excluded because tailor-made solutions are at odds with legal equality.

Escape logic. All parties involved in the education of (grand) children of foreign origin can escape the above logics via the escape logic. The escape logic is also referred to as inspired logic [20]. "Inspired logic ascribes value to inspiration, enlightenment and creativity, and to pursuit higher goals that transcend and transform obstacles of every day." The inspired logic provides a way out for a stalemate that can occur as a result of educational and bureaucratic logic and the logic of immigrants and refugees. Below is a search for indirect evidence of existence of these logic's in education.

\subsection{Educational Output Data as Evidence for Bureaucratic and Educational Logic}

The bureaucratic and educational logic can only be investigated via education output data. This is preceded by 
the question: can educational output data be used as an indication of the existence of an educational and bureaucratic logic? The answer is: direct measurements of bureaucratic and educational logic do not exist. The only indicators available are therefore the education output data. Examples of educational output data are social segregation at the front door of the school, early selection, absenteeism, teacheradvice and under-advice, up and downstream dropout in the education system, final tests, student monitoring system tests and stacking of study programs. In other words, are the output data that education has at its disposal, a tool to manage Dutch education in a targeted manner (central government, municipalities and education)? There is doubt about this.

\subsection{Segregation as Evidence for Bureaucratic and Educational Logic}

Output data on Dutch education broken down by origin of pupils and students are used as an indication of the success and failure of these pupils and students. "Highly differentiated education systems, such as the one in the Netherlands, have a major impact on social and ethnic inequality [21]. This inequality is shown by differences in results between fifteen-year-old students, after they have chosen for a 'pre-university' education (HAVO/VWO/Gymnasium) or vocational education (VMBO) and the chance of obtaining a diploma in these educational segments. Young pupils and students also suffer from early selection. As a result, motivated and talented children of immigrants and refugees do not have enough time to prove themselves in education. Their ultimate skills are lagging behind those of originally Dutch children, which are a bit muffled by (grand) child of foreign origin whose educators on average have a higher of education in their mother land. As mentioned earlier, early selection, such as in the Netherlands, can further strengthen inequality and segregation in education. At the same time, there appears to be no causal link between early selection and average educational performance in countries with a high level of development, well-trained teachers and not too big classes. Not only socio-ethnic segregation through education itself leads to early selection, but also preferences of parents and educators of children and schools at the front door of primary school can be seen as the causes of socio-ethnic segregation and therefore early selection [22]."

The result of the above is mentioned in the "State of Education' of the Education Inspectorate [18, pp. 14]: "the primary schools differ considerably in terms of the percentage of pupils who reach the reference levels ${ }^{1}$. In schools without pupils with an immigration background, the percentage of pupils who reach the target level varies greatly,

1 Since August 2010, the Reference Levels Dutch Language and Mathematics Act have been applicable. Reference levels ensure that secondary education connects well with primary education and then with secondary education (MBO, HBO, university). The levels determine which material a child must master in which phase of his school career. See https://www.heutinkvoorthuis.nl/nl/referentienalen-wat-betekent-ze/news/30/ between 47 and 86 percent (lower- and upper quintile). In schools where all pupils have an immigration background, the percentage of pupils who reach the target level varies between 18 and 69 percent (lower- and upper quintile). The lower quintile in schools with pupils who have an immigration background is almost $40 \%$ lower and the upper quintile about $80 \%$ lower than in schools with pupils without an immigration background. Comparable school differences are found in arithmetic." These differences between schools with and without an immigrant background are considerable. What the outcome would be, if all primary schools were included in this calculation is not clear, so if schools that are "black" and a little "white" or "white" and a little "black" would also be included in the above calculations.

\subsection{Conclusion of Logics as a Framework for Disadvantage and Deprivation: A Bankrupt Integration Policy}

A comment of Crul et al. [23] about the bureaucratic and educational logic is useful in this context: "The balancesheet for the intermediate and second generation can now be drawn up more than fifty years after the start of labour migration. Politics is equally powerful everywhere: integration policy is bankrupt. Inadequate language proficiency, large cultural differences and the low socioeconomic position of the first generation are identified as the causes of immigrant and refugee logic for "the failed integration" of the intermediate and second generation, exactly the characteristics on which the migrants were initially recruited by employers and the government. The major challenges associated with the education of young people whose educators are unable or hardly able to support their children are the direct result of choices made at the time by the government and employers on the basis of fairly short-sighted economic reasons [23]."

\section{Positive and Negative Developments with Regard to Disadvantage and Deprivation}

Statistics Netherlands (CBS) points out the following trend based on educational output data: "compared to 10 years ago, a larger proportion of pupils with a non-Western immigration background follow a higher level of education, both in 'preparatory university education' and vocational education. The same applies for pupils with a Dutch background. Nevertheless, the difference in participation at higher levels between pupils with a Dutch background and a non-Western background hardly diminishes [15]." With regard to these educational output data from Statistics Netherlands, the question must also be asked, do these data provide Dutch education with the correct insights? Do these insights provide central, and local governments and schoolboards with tools for program interventions that can turn disadvantage and deprivation into advantage and the opposite of (absolute and relative) deprivation? 


\subsection{A Positive Development: Extended Family Messages}

SCP research outlines the educational expectations of educators of children of immigrants: "many immigrant parents attach great importance to the good school performance of their children. This is also reflected in the way they talk about school with their child. In these conversations the emphasis often seems to be on performance, hard work and control. The emphasis on good school results reflects the desire and hope of immigrant educators that their children will be substantially better off than they themselves. In their view, good education is the key to success [24]."

In her doctoral dissertation, Rezai looked at study performances and executive jobs of children of immigrants from Turkey and Morocco [25]. She found that support of low-educated parents is crucial as one of the explanations for their children success. Educators, even if they are illiterate, can support their children. Educators give various conscious and unconscious messages to their children. Rezai [25] calls these messages 'extended family messages'. She found three types of extended family messages. The first is the 'joint mobility project'. Educators have come to the Netherlands to get it better here. That has not always been fulfilled. That goal is then passed on to the children. "They say: make sure you do better than I did [25]." The second extended family message is explaining the negative role model that educators have for their children. Educators often explain this as follows: "Look, I do hard physical work, receive little money and little appreciation. You can do this differently by doing your best at school, by studying, and by graduating." The same educators also often point to a positive role model within the extended family, an uncle or niece, who did a study and has a good job. They say: "Look, it's your niece. You can do this too! It is in your genes." The third extended family message is the comparison between their country of origin and the Netherlands. "They point out that education is accessible to everyone in the Netherlands. These opportunities are not present in Turkey and Morocco. Educators make their children aware that they must seize the opportunity to learn how to move forward [25]."

"The SCP shows that the language and arithmetic performance of the younger generations of (grand) children of foreign origin improve, and that they follow higher and higher levels in secondary education and further education [24]. The latter applies especially to girls and to a lesser extent to boys. The emphasis on school performance among educators may also show the concerns they have about school performance of their children: despite clear improvements, the educational performance of non-Western immigrant children is clearly lagging behind that of originally Dutch children. The SCP claims that this is partly due to the fact that migrant educators are lower educated and don't speak Dutch. Furthermore, the SCP says that these backlogs can also be caused by the way children are supervised at home." This claim from the SCP may be true, although Rezai shows something else. The SCP did not raise questions about education and the teacher herself. The SCP's explanation is a concrete example of the immigrant and refugee logic, namely that immigrants and refugees themselves are responsible for the 'bad' education results of their (grand)children, as if the responsible parties in the Netherlands for education have been relieved of any responsibility.

\subsection{Complaints About Education: Negative Developments with Regard to Deprivation}

The Netherlands has independent dispute committees, the majority of which are placed with the Education Disputes Foundation in Utrecht. The reports of this Utrecht Foundation don't distinguish between disputes of educators of (grand) children of immigrants and refugees and originally Dutch people. This is also the case at the Education Consumer Organization (OCO) in Amsterdam where questions and complaints come in and are processed by telephone [26]. OCO has a dashboard that specifies the number of questions/complaints per year, month and subject (origin of complainer or person who raises a question, is missing). An example is the following selection from this dashboard: 1) transfer from PO-VO, 2) assessment and 3) teacher-advice and final test. For the 2017-2018 period, the callers' files (total files 1,282), consist of assessment (230 files) and teacher-advice and final test (84 files). Unfortunately, this wonderful tool (calling OCO) is only accessible to people who speak Dutch, are not illiterate and who are skilled on the internet. According to Parool (the Amsterdam newspaper), $16 \%$ in Amsterdam is low-literate, in Amsterdam districts Southeast this is 37\%, North $25 \%$ and New-West 23\% [27].

Complaints can also be submitted to the Education Inspectorate and the information point for Parents \& Education [28]: "140 educators have complained about the school advice. Most complaints are about how the scores of the Cito-test are taken into account in the school advice and about schools that say that they cannot give students double advice, such as VMBO-HAVO or HAVO-VWO. In 2010, 32 percent of the students received double advice, and in 20082009 that was less than 20 percent. Double advice is still increasing. Peter Hulsen, director of Parents \& Education says that these educators suspect that they are not being heard by school, because they speak 'poor' Dutch, even though that is not said out loud. The educators, who complain, mention that the school only looks at the results of the last Cito test. This is unfavourable for children who have just scored lower on that test than on other final tests. Educators also report that the primary school takes too much account of the results of the final test in the teacher-advice. Schools themselves indicate that the results of tests from previous years and the behaviour of children are crucial in determining the teacheradvice. Peter Hulsen also says that double advice is annoying for high schools that want to place a child.

The Parents and Education information point also received ten complaints from parents who suspected that their foreign 
origin played a role in school advice. They have submitted these complaints because their children score at tests each time at HAVO level, but still receive an VMBO recommendation. Some fathers and mothers are also surprised by the school advice. For years they have heard that their child is doing well at school and then it appears that 'good' means advice for VMBO-T, vocational instead of 'preparatory university' education."

\section{Conclusion: Who Is Responsible for the Deprivation and Disadvantage of (Grand) Children of Foreign Origin in Dutch Education}

For half a century, (grand) children of foreign origin have been disadvantaged and deprived in Dutch education. This deprivation leads to a gap between (grand) children of foreign origin and (grand) children of originally Dutch descent. This gap has painful consequences for children and young people from foreign populations, such as the feeling that they are not allowed to participate in the Netherlands, stumbling in education along the way and having limited access to the labour market. The latter point, a low participation in the labour market, leads to a chronic shortage of skilled workers now and certainly in the next two decades.

This gap also has painful consequences for the Netherlands as a whole, because it creates a breeding ground for polarization instead of a Netherlands that meets the essential characteristics of 'all-inclusive multiculturalism' [29]. But that is not everything. 'Moroccan in Europe. Criminal in the Netherlands' is a title of a book that illustrates what the immigrant and refugee logic looks like in practice [30]. Bovenkerk shows that the Dutch view of how Moroccans raise their children can lead to Moroccan boys committing more crime. The parenting style of Moroccans is labelled by Dutch people as punitive and child abuse [30].

This article seeks explanations for deprivation and the gap between original Dutch pupils and students and original immigrants and refugee pupils and students. Possible explanations are systemic barriers and thresholds in education [10, 11, 23], excluding non-Western psychological expressions (individual and group-oriented), isolation and exclusion with consequences for short-term memory and cognitive skills [12] and fixed logics, such as that of immigrants and refugees, educational and bureaucratic logic. The consequences of disadvantage and deprivation for immigrant and refugee pupils and students have also been mapped out, such as taking longer to complete a course if necessary, absenteeism and dropout and less performance in language, mathematics and science [5], which means that the highest level of education turns out to be lower than expected.

Now that a large number of explanations for the deprivation of (grand) children of immigrants, refugees and expats in Dutch education have been clarified, an attempt is being made to determine who is responsible for the deprivation. A frame of reference to determine who is responsible is: education is a human right [31]. UNESCO states: "Education is a basic human right and the best investment that we can make to ensure a sustainable future and leave no one behind. This is true for every country and region. However, millions are deprived of educational opportunities every day, many as a result of social, cultural and economic excluding factors." Since 1948, almost every country in the world has signed at least one treaty guaranteeing the right to education. UNESCO expresses its concerns about this human right to education as follows [31, pp. 19]: "When people immigrate or are displaced internally or across borders, or where there is rapid urbanization, specific challenges arise in ensuring that the right to education is fulfilled." This human right to Education has been formulated in a colour-blind manner by saying that all people have the same right to education. This equal right to education means that every facility should not discriminate and also puts equality into practice. In this UNESCO report, the human right to education is further elaborated by specifying different groups of people that need to be taken into account, such as national, ethnic and linguistic minorities, indigenous people, immigrants, refugees, asylum seekers and stateless persons [31, pp. 85]. Less colour-blind are the statements in this UNESCO report on education in the 'New World' where all children learn regardless of their differences [31]. 'New World' education must overcome barriers by supporting people following education. 'New World' education should adapt education and the educational context so that the full individual potential of a pupil and student is utilized within a participatory learning environment.

But what should be done if there is a violation of this human right to education [31]? UNESCO puts the responsibility for these violations in the hands of Civil Society Organizations. The task for them is: a) hold states accountable for their legal obligations, b) bring education concerns to the attention of a state, c) monitor the right to education, d) expose violations, and e) address states on their responsibility. This overview should also include supervision of financially powerful Dutch education-software-businesses, such as Magister and ParnasSys, who don't provide any information about the quality of the teacher, class and school climate.

In short, UNESCO distinguishes two responsibilities to realize the right to education. First of all, all institutions (including private parties) that provide education and their governing bodies. In the second place, the UNESCO defined as responsible parties the bodies responsible for the plan, do, act and check management-cycle, such as government, parliament (second and first chamber of parliament), the Education Inspectorate, and municipalities. Finally, the violation of the right to education should also be high on the agenda of Civil Society Organizations, such as the (children) ombudsman, the national and local audit offices and dedicated research institutes. 


\section{References}

[1] Gianni, Stephania (2019). Right to Education. UNESCO. Sustainable Development Goals. Right to education handbook. (C) UNESCO and Right to Education Initiative, 2019.

[2] Amsterdamse rekenkamer (2017). Eindrapport. Armoedebeleid en de impact op kinderen. Tabel 4.1 (pp. 28).

[3] Onderwijsverslag (2019). De Staat van het Onderwijs. Inspectie van het onderwijs. Ministerie van Onderwijs, Cultuur en Wetenschap.

[4] Steinmetz, Carl H. D. (december 2018/ januari 2019). Verward gedrag en een niet-Nederlandse afkomst. Aanknooppunten voor preventie. Sociaalbestek. DOI: 10.1007/s41196-018-0167-7.

[5] OECD (2018). The resilience of students with an immigrant background: factor that shape wellbeing. OECD publishing, Paris.

[6] Onderwijsraad (2017). Vluchtelingen en onderwijs. Naar een efficiëntere organisatie, betere toegankelijkheid en hogere kwaliteit. Uitgave van de Onderwijsraad, Den Haag, 2017.ISBN 978-946121-056-2. Retrieved from: https://www.onderwijsraad.n1/upload/documents/publicaties/v olledig/Vluchtelingen-en-onderwijs.pdf

[7] Steinmetz, Carl H. D. (2018). Voorkom discriminatie, uitsluiting en polarisatie. Bevorder inclusie. Sociaalbestek. DOI: $10.1007 / \mathrm{s} 41196-018-0101-\mathrm{z}$.

[8] Onderwijsraad (2018). Doorgeschoten differentiatie in het onderwijs. Hoofdlijnen van Stand van Educatief Nederland 2018.

[9] Botermans, Willem en De Wolf, Inge (2018). Woonsegregatie bepaalt in grote mate schoolsegregatie. ESB. Gelijke kansen op school. Jaargang 103 (4768) 20 December 2018.

[10] Crul, Maurice (2018). How key transitions influence school and labour market carers of descendants of Moroccan and Turkish migrants in the Netherlands. European Journal of Education, 2018; 1-14. DOI: 10.1111/ejed.12310.

[11] Crul, M., Schneider, J. \& Lelie, F. (2017). The multiplier effect. How the accumulation of cultural a social capital explains steep upward mobility of children of low educated immigrants. Ethnic and Racial studies, 40, 321-338APA.

[12] Ftitache, Bouchra (2015). Psychosocial and educational adjustment of ethnic minority elementary school children in the Netherlands. Doctoral Dissertation, Vrije Universiteit Amsterdam.

[13] Van der Ven, Els (2015). Ethnic minority position as risk indicator for autism-spectrum and psychotic disorders. Doctoral Dissertation Maastricht.

[14] Bloemink, Sanne (2017). Armoede zie je terug in de hersenen. Voor een dubbeltje op de laatste rij. De Groene Amsterdammer. 12 april 2017. Retrieved from: https://www.groene.nl/artikel/voor-een-dubbeltje-op-delaatste-rij

[15] Hartgers, Marijke, Kuipers, Nelet, en Linder, Frank (2018). Hoofdstuk 2 Onderwijs uit Jaarrapport 2018. Centraal Bureau voor de Statistiek. (C) Centraal Bureau voor de Statistiek, Den Haag/Heerlen/Bonaire, 2018.
[16] Lek, Kimberley en Van der Schoot, Rens (2019). Wie weet het beter, de docent of de centrale eindtoets. De Psycholoog, maandblad Nederlands Instituut van Psychologen. Jaargang 54. Nr. 4. April 2019.

[17] Smeets, Ed, Van Kuijk, Jos en Driessen, Geert (2014). Handreiking bij het opstellen van het basisschooladvies. ITS, Radboud Universiteit Nijmegen.

[18] Onderwijsverslag (2018). De Staat van het Onderwijs. Inspectie van het onderwijs. Ministerie van Onderwijs, Cultuur en Wetenschap.

[19] Boltanski, L. \& Thévenot, L. (2009). On Justification: Economics of Worth. Princeton, NJ: Princeton University Press.

[20] Bredewold, Femmianne, Duyvendak, Jan Willem, Kampen, Thomas, Tonkens, Evelien en Verplanke, Loes (2018). De verhuizing van de verzorgingsstaat. Hoe de overheid nabij komt. Van Gennep Amsterdam.

[21] Dronkers, Jaap, Elffers, Louisse, Karsten, Sjoerd, van der Velden, Rolf \& Herman van der Werfhorst (2016). Groeiende ongelijkheid vraagt om ingrijpen. S \& D Jaargang 73, Nummer 2 April 2016.

[22] VandenBroucke, Anneloes, en Nouwen, Ward (2016). Voorkeuren ouders en scholen weken sociaal-etnische segregatie in het basisonderwijs in de hand. Acco, Leuven, Den Haag.

[23] Crul, Maurice, Schneider, Jens en Lelie, Frans (2013). Superdiversiteit. VU University Press.

[24] Bucs, Freek, en Rose, de, Simone (2015). Opvoeden in nietwesterse migranten gezinnen. Een terugblik en verkenning. Sociaal en Cultureel Planbureau, Den Haag 2015. SCPpublicatie, 2015-22.

[25] Rezai, Sara (2017). The Rise of the Second Generation. The role of social capital in the upward mobility of descendants of immigrants from Turkey and Morocco. Doctoral Dissertation Free University Amsterdam.

[26] Sariwating, Kaja en Koppel, van de Menno (2018). OCO in cijfers. Rapportage over cijfers helpdesk en informatievoorziening en trends schooljaar 2017-2018 in vergelijking met OCO door de jaren heen. Onderwijs Consumenten Organisatie.

[27] Piersma, Jasper (2016). In Zuidoost is 37\% laaggeletterd. Parool. https://www.parool.nl/nieuws/in-zuidoost-is-37procent-laaggeletterd $\sim \mathrm{bc} 37 \mathrm{a} 621 \mathrm{~b} /$

[28] Winters, Bettine (2017). 140 klachten over schooladvies. https://www.ad.nl/binnenland/140-klachten-overschooladvies $\sim$ ac $5 \mathrm{c} 931 \mathrm{c} /$

[29] Zee, van der, Karin (2015). Expanding horizons: Intercultural competency of individuals and organizations. Inaugural speech, May 22, 2015. Vrije Universiteit Amsterdam.

[30] Bovenkerk, Frank (2014). Marokkaan in Europa, crimineel in Nederland. Boom Lemma uitgevers.

[31] UNESCO (2019). Right to Education Handbook. Published in 2019 by the United Nations Educational, Scientific and Cultural Organization (UNESCO) 7, place de Fontenoy, 75352 Paris 07 SP, France and Right to Education Initiative, c/o ActionAid International 33-39 2017). Bowling Green Lane, EC1R OBJ London, United Kingdom. 